http://journal.uinsgd.ac.id/index.php/biodjati

\title{
DISTRIBUTION AND CHARACTERISTICS OF JAVAN HAWK EAGLE NESTING TREES IN GUNUNG HALIMUN SALAK NATIONAL PARK, INDONESIA
}

\section{Wardi Septiana1, Ahmad Munawir ${ }^{2}$, Pairah ${ }^{3 *}$, Moch. Erlan Sodahlan ${ }^{4}$, Yosi Irawan', Yanto Santosa $^{6}$, Lilik Budi Prasetyo ${ }^{7}$}

Received : May 09, 2020

Accepted : October 17, 2020

\section{DOI: 10.15575/biodjati.v5i2.8481}

1,2,3,4,5 Gunung Halimun Salak National Park Agency, Jl. Raya Cipanas Kecamatan Kabandungan Kabupaten Sukabumi, Jawa Barat 43368

${ }^{6,7}$ Department of Forest Resources Conservation and Ecotourism, Faculty of Forestry and Environment, IPB University, Jl. Ulin Lingkar Akademik Kampus IPB, Dramaga Bogor 16680, Jawa Barat, Indonesia

e-mail:

'warfa999.halimun@gmail.com

wiratns@gmail.com

*3andriphe@yahoo.com

elansodahlan@gmail.com

5yosiirawan78@gmail.com

6yantohaurjaya@yahoo.co.id

'lbprasfb@gmail.com

\begin{abstract}
Javan Hawk Eagle is one of the three keys species of the Gunung Halimun Salak National Park and endemic to the island of Java. Protecting the active Javan Hawk Eagle nesting tree is one of the efforts to increase the success rate of Java Hawk Eagle breeding so that information on the distribution and characteristics of Javan Hawk Eagle nesting tree is needed. Field exploration was carried out to determine the existence of the Javan Hawk Eagle nest. There were 10 individuals of Javan Hawk Eagle nesting trees which consisted of five species namely Rasamala, Huru, Damar, Lengsar and Manggong with tree architecture models of rauh, massart, scarrone and aubreville, tree height between 26-55 $\mathrm{m}$ and height of nests between 18-41 m. The Javan Hawk Eagle nesting trees grow in primary, secondary, and plantation forests in a height between 670-1295 masl, with a steep and very steep slope, the majority of the distance from the river is less than $100 \mathrm{~m}$ and the majority of the distance with ecotone is less than $600 \mathrm{~m}$. Javan Hawk Eagle nest on Damar is the first finding at Gunung Halimun Salak National Park.
\end{abstract}

Keywords: Javan Hawk Eagle, nest, Halimun-Salak

*Corresponding author

\section{Citation}

Septiana, W., Munawir, A., Pairah, Sodahlan, M. E., Irawan, Y., Santosa, Y. \& Prasetyo, L. B. (2020). Distribution and Characteristics of Javan Hawk Eagle Nesting Trees in Gunung Halimun Salak National Park, Indonesia. Jurnal Biodjati, 5(2), 182-190.

\section{INTRODUCTION}

Javan Hawk Eagle is one of the three Gunung Halimun Salak National Park key species, two others are Javan gibbons and Javan leopards. Javan Hawk Eagle is endemic to Java Island, categorized as endangered species by IUCN red list 2017 and protected species by The Indonesian Government. The
Ministry of Forestry of Republic Indonesia has prepared a Strategy and Action Plan for the Conservation of the Javan Hawk Eagle in 2013, as an effort to conserve this animal.

Javan Hawk Eagle only breeds once a year, with an incubation period of $47 \pm 1$ days (Kementerian Kehutanan, 2013). So, the nesting period is the most important phase in the life cycle of raptor birds for their existence 


\section{JURNAL BIDDJATI}

http://journal.uinsgd.ac.id/index.php/biodjati

continuity (Withaningsih et al., 2017b). Moreover, Bialas et al. (2020), said that choosing an appropriate nest site is essential for successful breeding. Therefore, one of the action plans to increase the Javan Hawk Eagle breeding success is by protecting their active nesting trees.

There are some studies of Javan Hawk Eagle that have been done in Gunung Halimun Salak National Park including Study of Javan Hawk Eagle Population in Mount Salak (Pribadi, 2014), Spatial Modelling of Javan Hawk Eagle Habitat (Cahyana, 2015), Ecological Monitoring of Javan Hawk Eagle Nests in Cikaniki - Gunung Halimun Salak National Park (Ridwan et al., 2004), and Study of Habitat and Population of Javan Hawk Eagle in Cipinang Gading and Bobojong - Gunung Halimun Salak National Park (Pusat Penelitian dan Pengembangan Konservasi dan Rehabilitasi, 2014). However, the information about nesting trees distribution and characteristics in Gunung Halimun Salak National Park is still limited and has not widely published. Hence, this study is important to be conducted for supporting the Javan Hawk Eagle Conservation Action Plan in Gunung Halimun Salak National Park.

\section{MATERIALS AND METHODS}

Data Collection was done by using the field exploration methods in the potential locations which were determined based on the information from the local community and from Gunung Halimun Salak National Park Agency's database to identify the existence of Javan Hawk Eagle nests. Every nesting trees found in the field were measured (total tree height and nest height above the ground), documented by using cameras and drones and its location coordinates were also recorded. The data collection was conducted from April to June 2019.
The distribution analysis of Javan Hawk Eagle nesting trees was based on the data of land cover, contour, slope, the distance to stream, and ecotone. The map of land cover was gained from the National Survey and Map Coordination Body (Bakosurtanal) while the maps of contour and slope were obtained from Digital Elevation Model (DEM) which was further classified by using Spatial Analysis Tool in software ArcGIS 10.2. The coordinate points of nesting trees were plotted on the maps of land cover, altitude class, slope class, and stream buffer.

The analysis of Javan Hawk Eagle nesting trees was based on trees height, nest height, and trees architecture model. The trees and nest height were classified and its percentages were counted. The trees architecture model was identified based on literature.

\section{RESULTS AND DISCUSSION}

\section{The Distribution of Nesting Trees}

The exploration activities identified ten active nesting trees in the research site. Based on the land cover map, nesting trees were most likely to be found in the secondary forest $(60 \%)$, followed by in the primary forest $(30 \%)$ and most unlikely to be found in the plantation forest (10\%) (Figure 1). The existence of the Javan Hawk Eagle in the plantation forest, however, is a new fact showing that the Javan Hawk Eagle is also willing to build their nest in the plantation trees (Agathis damara). Kementerian Kehutanan (2013) said that Javan Hawk Eagle often uses secondary forest close to the primary forest as the area for nesting and hunting, even though its home range encompasses a variety of habitat types including production (homogenous) forest, cultivation and plantation areas. Sitorus \& Herwono (2017) reported that Javan Hawk Eagle used the low land fo- 


\section{JURNAL BIDDJATI}

http://journal.uinsgd.ac.id/index.php/biodjati

rest and plantation forest in Alas Purwo National Park.

The nesting trees distribution analysis based on altitudes found that six nesting trees were located in the altitude of $1000-1500$ above sea level (asl), while the four other nesting trees were grown in the altitude of $500-1000$ asl (Figure 2). This fact is in line with the result of research by Pusat Penelitian dan Pengembangan Konservasi dan Rehabilitasi (2014) that showed the nesting trees have been found at the altitude of 1.111 asl in Cipinang Gading and in the altitude of 968 in Bobojong. However, based on Ridwan et al. (2014), the nesting tree has also been found at the altitude of 1760 asl in the Cikaniki Forest.

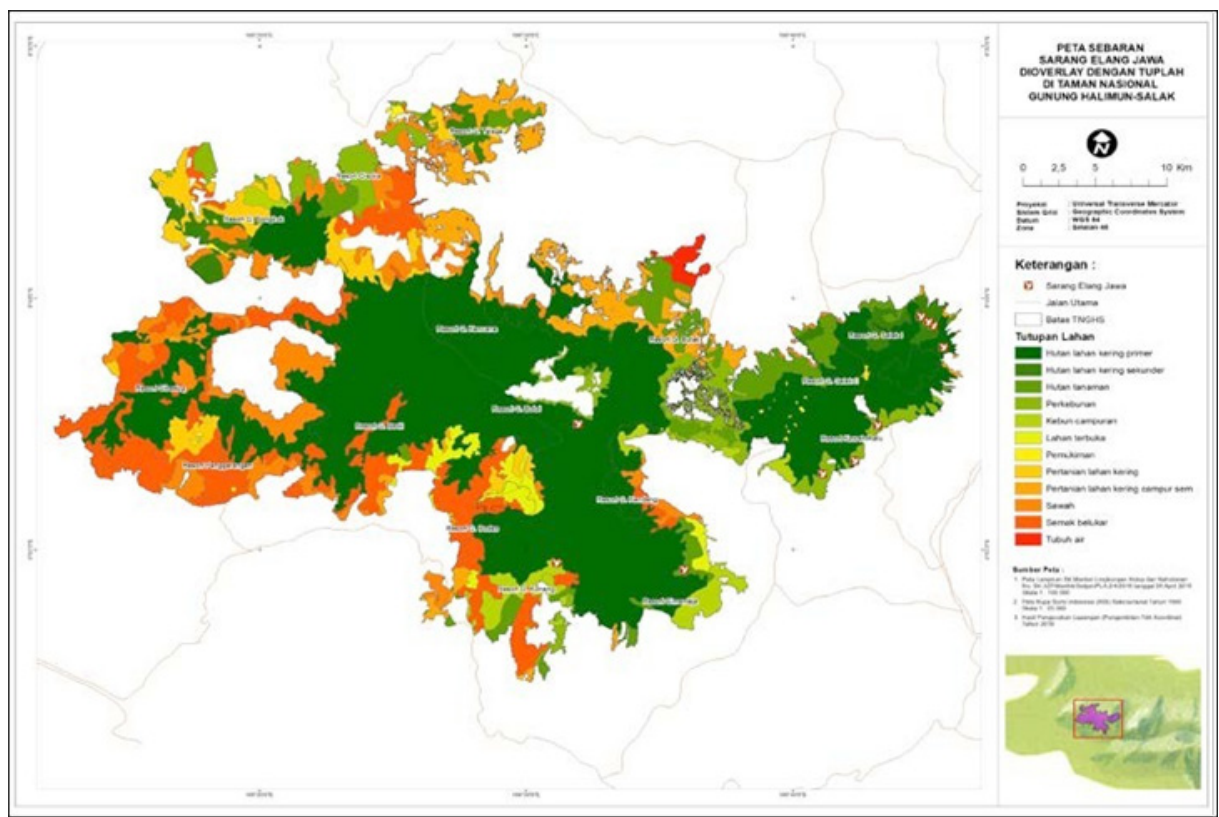

Figure 1. The distribution of the nesting trees based on land cover map

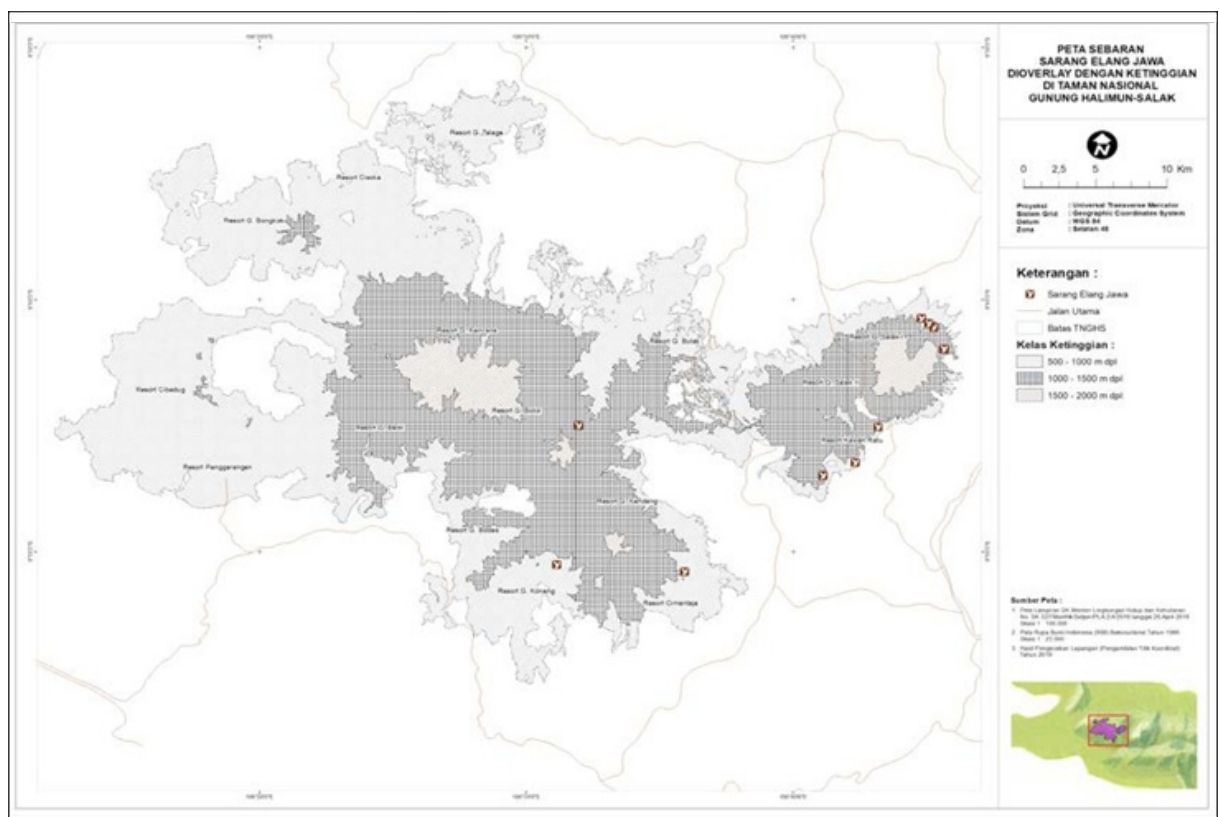

Figure 2. The distribution of the nesting trees based on altitude map 


\section{JURNAL BIDDJATI}

http://journal.uinsgd.ac.id/index.php/biodjati

The nesting trees distribution analysis result based on the slope (Figure 3) showed that the majority of the nesting trees (six trees) were found in the place with more than $40 \%$ slopes (extremely steep) while four nesting trees were located in the area of 25 - 40\% slopes (Steep). Pusat Penelitian dan Pengembangan Konservasi dan Rehabilitasi (2014) has also found nesting trees grown in the extremely steep area and Gunawan et al. (2016) found Javan Hawk Eagle nesting trees found at an average steepness of the slope was $57.50^{\circ}$.

Pusat Penelitian dan Pengembangan Konservasi dan Rehabilitasi (2014), moreover, stated that in general, the Javan Hawk Eagle nests could be found in the trees located in the area with moderate to the steep slope, the altitude more than 800 asl, and the stream at the down valley. It relates to the parents' convenience in hunting while taking care of the juvenile. Withaningsih et al. (2017b) concluded that the area around the Javan Hawk Eagle nests were areas that had been deemed suitable to build nests, but because of a disturbance, either by nature (the breakage of the nesting branch) or by human activity (the creation of pathway around the nesting tree or the poaching of the Eagles' eaglet) then a relocation to another nesting tree still in the same area was needed.

The next analysis, based on the distance between the nesting trees and streams, showed that the majority of the nesting trees, which is five trees or $50 \%$ of the nesting trees identified, grew in the distance of about 50 to 100 meters from streamlines, while three trees grew in the distance of 0 to $50 \mathrm{~m}$ from the streamlines and only a tree grew in a place of about 200 to 250 meters from streamline, yet close to an irrigation channel (Figure 4).

Lastly, based on the distance to ecotone showed that Javan Hawk Eagle in the research site chose nesting trees in the distance of about 144 to 887 meters to ecotone, and $40 \%$ of the nesting trees identified were located in the distance of about 400 to 600 meters to ecotone (Figure 5).

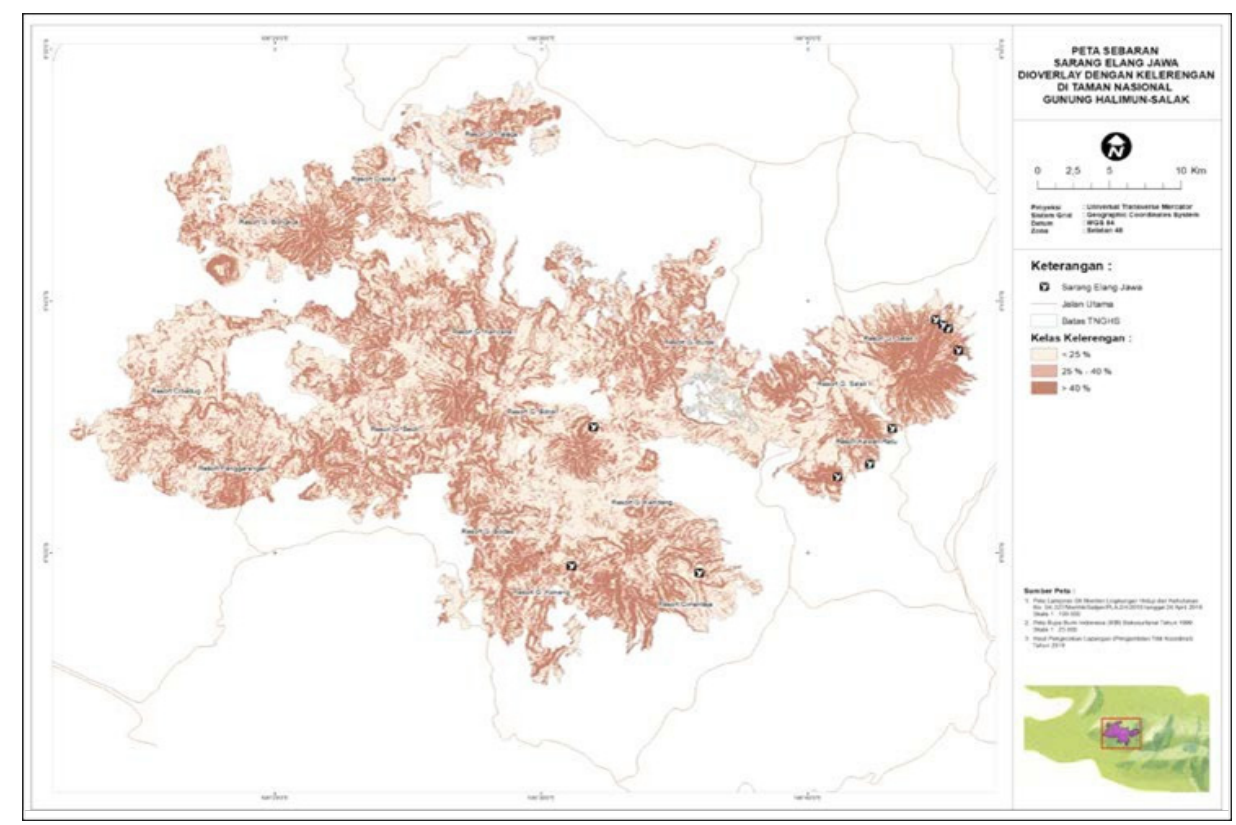

Figure 3. The distribution of the nesting trees based on slope map 
Jurnal Biodjati 5(2):182-190, November 2020

\section{JURNAL BIDDJATI}

http://journal.uinsgd.ac.id/index.php/biodjati

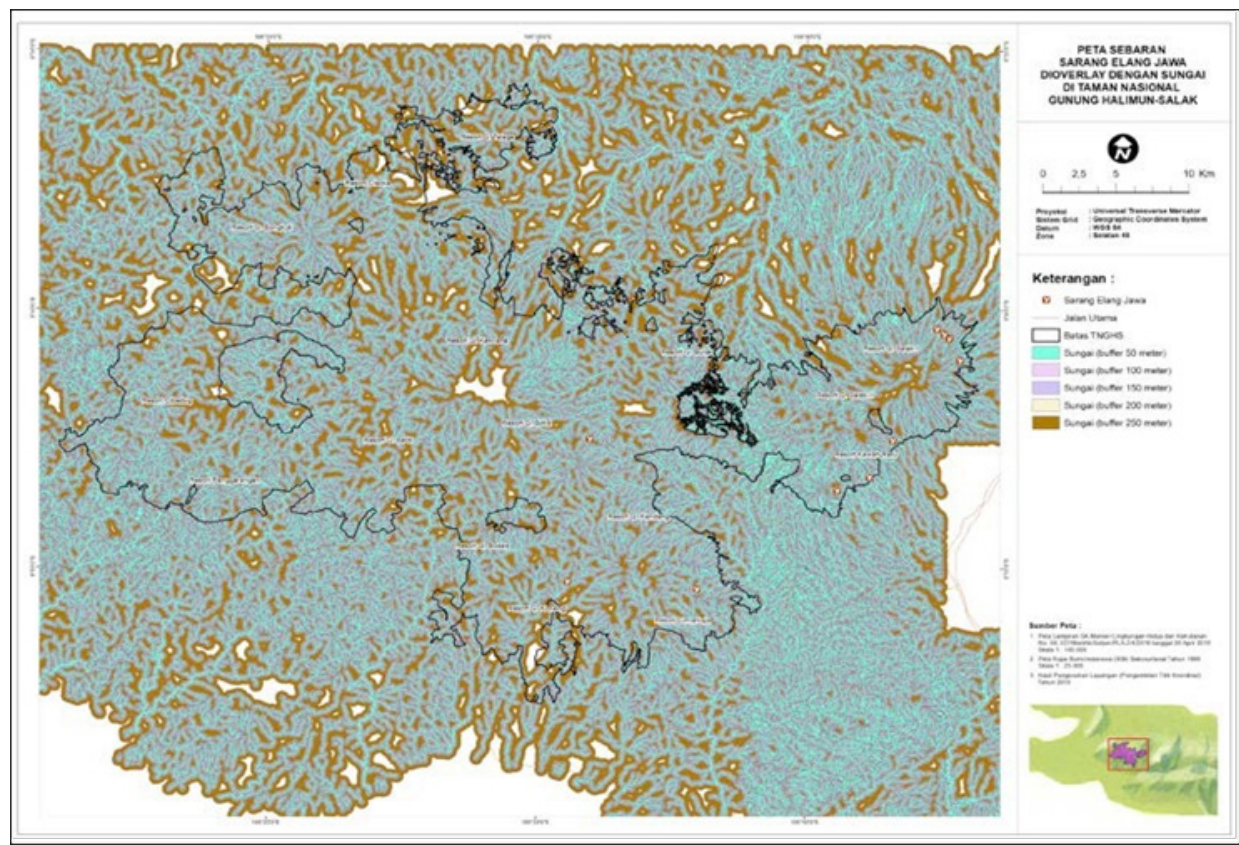

Figure 4. The distribution of the nesting trees based on the distance to streamline map

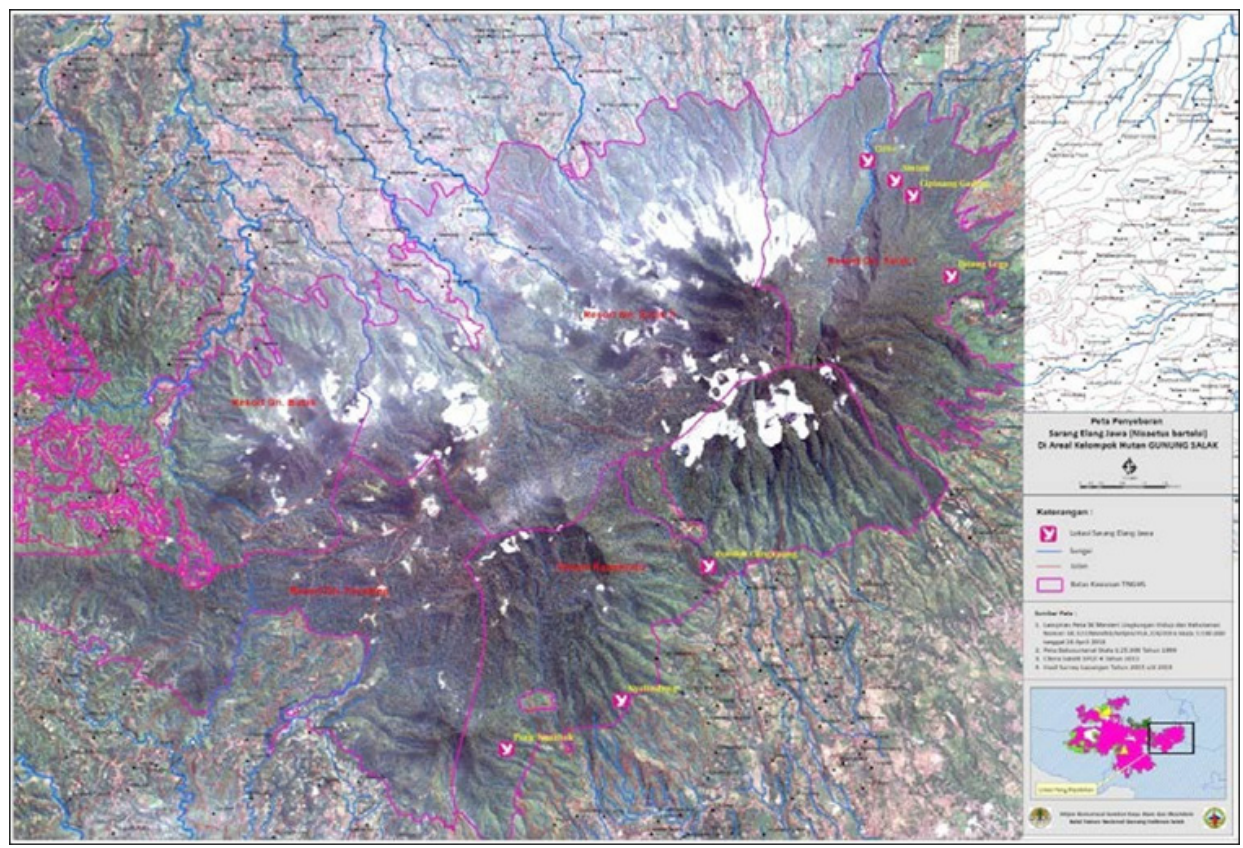

Figure 5. The distribution of the nesting trees based on the distance to ecotone

The choice of nesting trees close to the ecotone is also related to the parents' ease in hunting in the ecotone area or in the neighboring plantation or rice field areas. Azmi et al.
(2016) also reported that Javan Hawk Eagle used the natural forest for nesting, while the garden, shrub, and agricultural area were used for hunting area. 


\section{JURNAL BIDDJATI}

http://journal.uinsgd.ac.id/index.php/biodjati

\section{The Characteristic of Nesting Trees}

The Nesting Trees Architecture

As mentioned earlier, there are 10 nesting trees found during this period of research (Table 1). The nesting trees dominated by species Rasamala (Altingia excelsa) and Huru (Litsea sp.) which have the architecture model of "Rauh" (Table 2). This model shows the branching composed by the rhythmic grown monopodial stem, monopodial and orthotopric branches. The trees' canopy looks like a vase, which is narrow in the bottom and wider in the top (Ekowati et al., 2017). This canopy model, furthermore, enables better nest protection from the rain or predator attacks. However, this study also found a nest that was built on a "Damar" tree (Agathis damara) which has massart type of tree architecture model with lateral branching and this was the first finding at Gunung Halimun Salak National Park. These findings enrich the information on tree types used by Javan Hawk Eagle for nesting. Sitorus \& Hernowo (2017) said that large and horizontal branches make it easier for Javan Hawk Eagle to build the nests.

\section{Trees and Nest Height}

The nesting trees' height identified in the field was ranging from 26 to $55 \mathrm{~m}$ with an average height of $43 \mathrm{~m}$. Moreover, most of the trees $(30 \%)$ have 51 to $55 \mathrm{~m}$ in height. The nests itself moreover were mostly built on the branches at a height ranging from 31 to $35 \mathrm{~m}(30 \%$ of the nest) (Figure 6$)$. While Ridwan et al. (2014) found a nesting tree of Castanopsis argentea with height reaches of about $40 \mathrm{~m}$ and the nest laid lower at the height of $16 \mathrm{~m}$. All the nesting trees found in the field were emergent trees and protrude from the surrounding trees with a wide view. Ridwan et al. (2014) stated that this condition facilitated the Eagle parents to move in and out of the trees and oversee the nests from distance. The tallest tree was used as a nest tree because it can provide a wide view from the nest as well as to the nest. Javan Hawk Eagle spent outside the nest were primarily aimed to find food, investigate, and move to areas around the nest (Withaningsih et al., 2017a).

The main function of the nest is to provide suitable places for the Eagle parents to lay their eggs and take care of the juveniles. In addition, the need of minimizing the risks of predator attacks is the most influential factor in choosing the nests' location as well as its design (Mainwaring et al., 2014). Moreover, the height of the nests also determines the predatory attack risk level and, besides, putting nests on the trees has a lower risk than putting them on the ground (Whyte et al., 2005). Furthermore, Mainwaring et al. (2014) said that putting the nests on the trees canopy will minimize the predator attack risks as well as protect them from the rains.

The materials of the nest also determine the microclimate of the nests for the hatching process of the eggs (Mainwaring et al., 2014). The materials that form the Javan Hawk Eagle nest found in the field consist of twigs and leaves. We also found that Javan Hawk Eagle used epiphytic plants (Paku Tanduk Rusa (Platycerium bifurcatum), a kind of ferns) as it's nest as confirmed by Nadkarni \& Matelson (1989).

Table 1. The types of Javan Hawk Eagle nesting trees

\begin{tabular}{cccc}
\hline Family & Latin Name & Local Name & Amount \\
\hline Altingiaceae & Altingea excelsa & Rasamala & 4 \\
Lauraceae & Litsea sp. & Huru Hiris & 3 \\
Euphorbiaceae & Macaranga rhizinoides & Manggong & 1 \\
Araucariaceae & Agathis dammara & Damar & 1 \\
Sapindaceae & Nephelium juglandifolium & Lengsar & 1 \\
\hline
\end{tabular}

Pairah et al. 
Jurnal Biodjati 5(2):182-190, November 2020

\section{JURNAL BI@DJATI}

http://journal.uinsgd.ac.id/index.php/biodjati

Table 2. Nesting Trees Species and architecture models

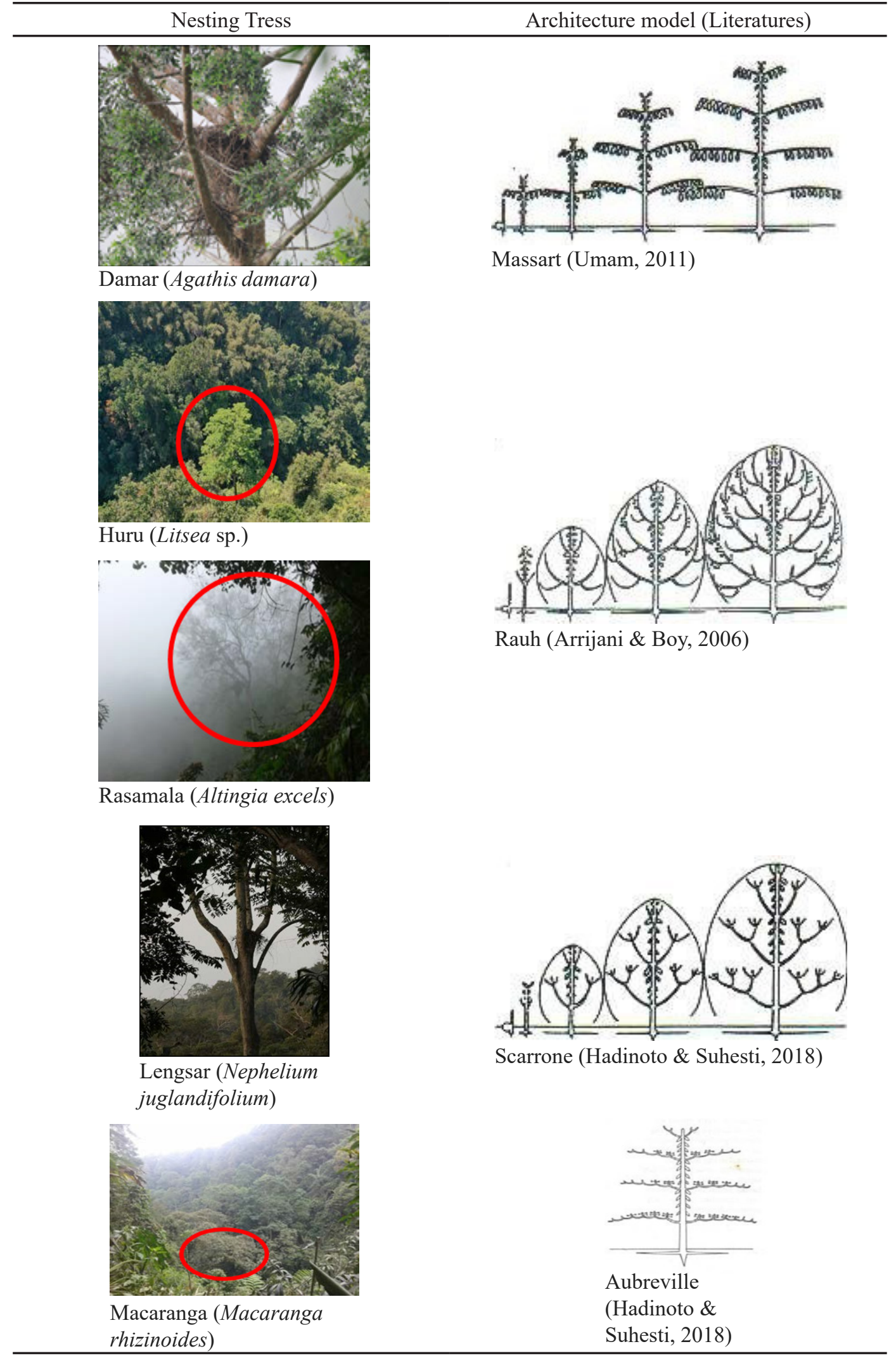

Jurnal Biodjati 5(2):182-190, November 2020 


\section{JURNAL BIDDJATI}

http://journal.uinsgd.ac.id/index.php/biodjati

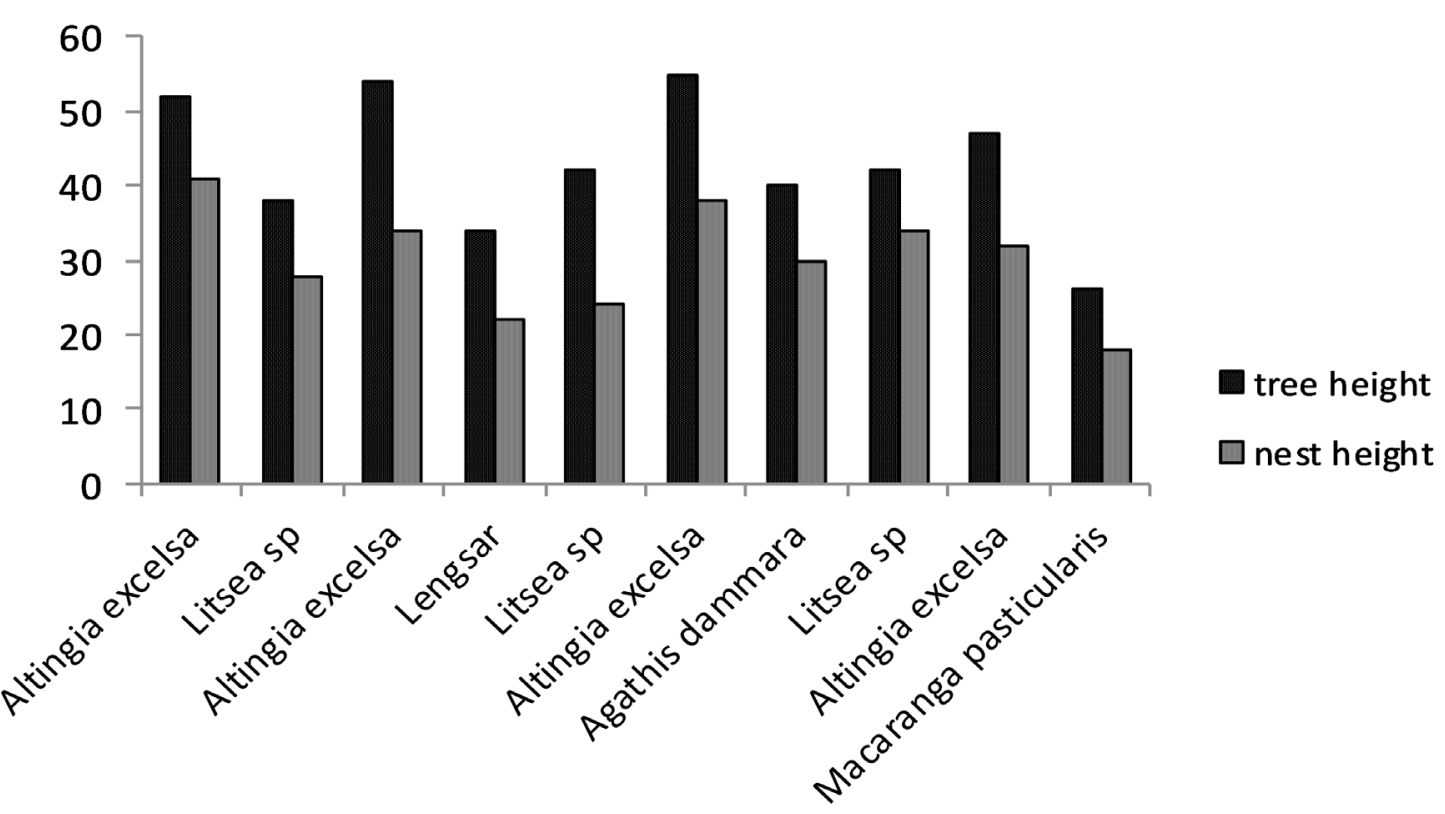

Figure 6. Nesting trees and the nests height

This study has found 10 active Javan Hawk Eagle nesting trees consisting of 5 tree species which are: Rasamala (Altingia excels), Huru (Litsea sp.), Damar (Agathis damara), Lengsar (Nephelium juglandifolium), and Manggong (Macarangapasticularis) with four trees architecture models, which are "Rauh", Massart, Scarrone and Aubreville. These canopy models are easier for Javan Hawk Eagle to build the nests and better nest protection from the rain or predator attacks. The nesting trees' height is ranging from 26 to $55 \mathrm{~m}$ and the nest height is ranging from 18 to $41 \mathrm{~m}$. In general, the Javan Hawk Eagle nesting trees grow in the primary, secondary, and plantation forest with the altitude of about 670 to 1259 asl at the steep to extremely steep slopes at the distance of less than $100 \mathrm{~m}$ from streamlines and mostly at less than $600 \mathrm{~m}$ from ecotone.

To complement this research results, which is about the distribution and characteristic of Javan Hawk Eagle nesting trees, further research about Javan Hawk Eagle parents behavior while nesting period and the development of the Javan Hawk Eagle JuPairah et al. venile from eggs period until growing as the independent individual should be conducted to provide more data needed in implementing the Javan Hawk Eagle Conservation Action Plan in Gunung Halimun Salak National Park.

\section{ACKNOWLEDGEMENTS}

We would like to thank Gunung Halimun Salak National Park Agency for facilitating this research. We also wish to thank Deddy Effendi, Sukiman, Yopi, Otang, Jamaludin, Deni, Dadang and Teguh for assistance in collecting of field data.

\section{REFERENCES}

Arrijani \& Boy J. A. (2006). Model Arsitektur Pohon pada Hulu DAS Cianjur Zona Sub-Montana Taman Nasional Gunung Gede Pangrango. Jurnal Matematika, Sains dan Teknologi, 7(2), 71-84.

Azmi, N., Syartinilia \& Mulyani Y. A. (2016). Model Distribusi Spasial Habitat Elang Jawa (Nisaetus bartelsi) yang Tersisa di 


\section{JURNAL BIDDJATI}

http://journal.uinsgd.ac.id/index.php/biodjati

Jawa Barat. Media Konservasi, 21(1), 9-18

Bialas, J. T., Dylewski, L. \& Tobolka, M. (2020). Determination of Nest Occupation and Breeding Effect of the White Stork by Human-mediated Landscape in Western Poland. Environmental Science and Pollution Research, 27, 4148-4158

Cahyana, A. N. (2015). Pemodelan Spasial Kesesuaian Habitat Elang Jawa (Nisaetus bartelsi Stresemann, 1924) Di Taman Nasional Gunung Halimun-Salak. Tesis. Bogor: Sekolah Pascasarjana Institut Pertanian Bogor.

Kementerian Kehutanan. (2013). Peraturan Menteri Kehutanan Republik Indonesia Nomor: P.58/Menhut-II/2013 Tentang Strategi dan Rencana Aksi Konservasi Elang Jawa (Spizaetus bartelsi) Tahun 2013-2022. Jakarta: Departemen Kehutanan.

Gunawan, Nani, Fauziah, R., Zulham, Djamaludin, Pramono, H. \& Yuniar, A. (2016). New Homes on Misty Mountains: Javan Hawk-eagle Nisaetus bartelsi and Changeable Hawk-eagle Nisaetus cirrhatus Nesting in Gunung Halimun Salak National Park, West Java, Indonesia. PODOCES, 11(1), 1-6

Hadinoto \& Suhesti E. (2018). Model Arsitektur Pohon Arboretum Universitas Lancang Kuning sebagai Penunjang Pembelajaran. Wahana Forestra: Jurnal Kehutanan, 13(1), 39-54.

Mainwaring, M. C., Hartley, I. R., Lambrechts, M. M. \& Deeming, D. C. (2014). The Design and Function of Birds' Nests. Ecology and Evolution, 4(20), 3909-3928

Nadkarni, N. M. \& Matelson, T. J. (1989). Bird Use of Epiphyte Resources In Neotropical Trees. Condor, 91(4), 891-907.

Pribadi, D. P. (2014). Studi Populasi Elang
Jawa (Spizaetus bartelsi Stresemann, 1924) di Gunung Salak. Bioma, 10(1), 17-24.

Pusat Penelitian dan Pengembangan Konservasi dan Rehabilitasi. (2014). Sintesis Hasil Litbang 2010-2014. RPI 12 Konservasi Flora, Fauna dan Mikroorganisme. Badan Penelitian dan Pengembangan Kehutanan. Jakarta: Kementerian Kehutanan.

Ridwan, I., Mulyadi, A. T. \& Rusli, A. R. (2014). Pemantauan Ekologi Sarang Elang Jawa (Spizaetus bartelsi) Di Wilayah Hutan Cikaniki, Taman Nasional Gunung Halimun Salak. Jurnal Nusa Sylva, 14(2), 43-46.

Sitorus, D. N. \& Hernowo, J. B. (2016). Habitat dan Perilaku Elang Jawa (Nisaetus bartelsi) di SPTN 1 Tegaldlimo Taman Nasional Alas Purwo, Jawa Timur. $\mathrm{Me}$ dia Konservasi, 21(3), 278-285

Umam, N. R. (2011). Hubungan Model Arsitektur Massart Dari Pohon Agathis damara L. C. Richard dengan Konservasi Tanah Dan Air Di RPH Gambung Petak 27 Area PHBM, KPH Bandung Selatan. Tesis. Bogor: Sekolah Pascasarjana Institut Pertanian Bogor.

Withaningsih, S., Parikesit, Iskandar, J. \& Hadi, F. (2017a). Studi Ekologi Lanskap di Sekitar Sarang Burung Pemangsa Di Kawasan Telaga Warna. Jurnal ProLife, 4(2), 347-363.

Withaningsih, S., Parikesit, Iskandar, J. \& Megantara E. N. (2017b). Breeding Behaviour of Differrent Raptor Species in human Modified Landscape. Biodiversitas, 18(3), 1234-1242.

Whyte, B. I., Didham, R. K. \& Briskie, J. V. (2005). The Effects of Forest Edge and Nest Height on Nest Predation in Two Differing New Zealand Forest Habitats. New Zealand Nat. Sci., 30, 19-34. 